\title{
Peran Mediasi Locus of Control pada Perilaku Keuangan
}

\author{
Asep Saepuloh', Sukaris ${ }^{2}$ \\ Progran Studi Manajemen, Fakultas Ekonomi dan Bisnis \\ Universitas Muhammadiyah Gresik, Indonesia \\ asep@umg.ac.id ${ }^{1}$, sukaris21@umg.ac.id ${ }^{2}$
}

\begin{abstract}
Financial problems for the next five to ten years are spending greater than income, increasing loans, and not being able to have a place to live because income and housing installment costs are not balanced, on the other hand Indonesian people's awareness of the importance of financial literacy is currently low. The purpose of this study was to determine the mediating role of the locus of control between financial knowledge, financial attitudes towards financial management behavior. The sample used 100 respondents, the analysis technique used structural equation modeling with WarpPLS. The results show that internal and external locus of control variables are not mediating variables between financial knowledge, financial attitudes towards financial management behavior.
\end{abstract}

Keywords: locus, financial, knowledge, behavioral, attitude, management.

\begin{abstract}
ABSTRAK
Persoalan keuangan lima sampai sepuluh tahun ke depan adalah pengeluaran lebih besar dari pendapatan, pinjaman bertambah, dan tidak dapat memiliki tempat tinggal karena pendapatan dan biaya cicilan rumah yang tidak seimbang, disisi lain kesadaran masyarakat Indonesia terhadap pentingnya literasi keuangan saat ini masih rendah. Tujuan penelitian ini mengetahui peran mediasi locus of control antara pengetahuan keuangan, sikap keuangan terhadap Perilaku manajemen keuangan. Sampel yang digunakan 100 responden, Teknik analisis yang digunakan struktural equation modeling (WarpPLS). Hasil menunjukkan bahwa variabel locus of control internal dan eksternal bukan varibel mediasi antara pengetahuan keuangan, sikap keuangan terhadap perilaku manajemen keuangan.
\end{abstract}

Kata kunci: Locus, Keuangan, Sikap, Perilaku, Manajemen.

\section{PENDAHULUAN}

Perilaku keuangan merupakan kemampuan mengatur keuangan sebaik mungkin atau dalam istilah lain bertanggungjawab (Al Kholilah $\mathrm{Rr}$ Iramani, 2013). Sumber pengetahuan dapat diperoleh dari pendidikan yang bersifat formal seperti kuliah, seminar dan pelatihan maupun informal seperti lingkungan sosialnya (Ida \& Dwinta,
2010). Pengetahuan keuangan akan dapat mempengaruhi locus of control dan perilaku keuangan jika memiliki pengetahuan pengelolaan keuangan yang baik, pengetahuan terhadap investasi dan lembaga keuangan.

Pankow, (2010) menyatakan sikap sebagai ukuran dari kondisi pikiran, pendapat dan penilaian 
tentang dunia yang kita tinggali serta mencerminkan posisi yang telah diambil dengan nilai-nilai dan jauh lebih fleksibel daripada nilai-nilai. Locus of control (LOC) kepercayaan seseorang mengenai apa penyebab dalam kehidupannya dan bagaimana seseorang memberikan respon sumber kejadian tersebut dari dalam atau dari luar individu tersebut. Konstruk LOC diartika sebagai kecenderungan umum yang relatif stabil untuk melihat dunia dengan cara tertentu, menangkap kepercayaan umum tentang penyebab imbalan dan hukuman (Rotter, 1966).

Rotter membagi locus of control internal dan locus of control eksternal. Penelitian (Perry \& Morris, 2005) menunjukkan bahwa LOC memiliki dampak signifikan pada perilaku manajemen keuangan yang bertanggungjawab baik secara langsung maupun tidak langsung, meski dampak ini kecil dalam banyak kasus. Secara khusus, LOC secara parsial memediasi pengaruh pengetahuan keuangan dan pendapatan pada perilaku keuangan. locus of control internal akan dapat mempengaruhi perilaku keuangan jika seseorang percaya diri, merasa puas dan juga bekerja keras sedangkan locus of control eksternal akan dapat mempengaruhi perilaku keuangan jika tidak merasa beruntung, tidak inisiatif dan tidak suka bekerja keras

Perilaku keuangan telah banyak dilakukan oleh peneliti bidang keuangan khususnya manajemen keuangan perilaku (Fernandes, Jr, Netemeyer, \& Fernandes, 2014; Mandell \& Klein, 2009; Perry \& Morris, 2005; Scafidi \& Skimmy-, 2016), begitu juga dikaitkan dengan perilaku manajemen keuangan yang dikaitkan dengan perbedaan generasi juga telah dilakukan (Annamaria Lusardi, 2010; Berry, Karlan, \&
Pradhan, 2018; Garg \& Singh, 2018; Lusardi \& Olivia S. Mitchell, 2007; Sohn, Joo, Grable, Lee, \& Kim, 2012; Supanantaroek, Lensink, \& Hansen, 2017), namun demikian penelitian dalam konteks Indonesia, dikaitkan dengan perilaku keuangan generasi saat ini belum banyak dilakukan, begitu juga belum jelasnya pengetahuan keuangan dalam mempengaruhi perilaku keuangan (Herdjiono \& Damanik, 2016; Mandell \& Klein, 2009), dan penelitian sebelumnya melibatkan locus of control masih menjadi variabel undimensional dan belum menjadi variabel multidimensional antara locus of control internal dan locus of control eksternal. Berdasarkan fenomena tersebut maka tujuan penelitian adalah peran mediasi locus of control antara pengetahuan keuangan, sikap keuangan terhadap perilaku manajemen keuangan.

\section{TINJAUAN PUSTAKA}

Ricciardi \& Simon, (2000) menyataka perilaku keuangan adalah suatu disiplin ilmu dengan berbagai interaksi tentang disiplin ilmu dan terus menerus beritegrasi. Nababan \& Sadalia, (2012), financial factor yakni: membayar tagihan tepat waktu, perencanaan dan mencatat anggaran pengeluaran dan belanja, menyediakan dana tak terduga, menabung, dan membedakan harga antar toko sebelum melakukan pembelian.

Penelitian lain membuktikan, pengetahuan keuangan disebut sebagai dimensi utama keuangan literasi (Huston, 2010) dan sebagian besar waktu dianggap sebagai sinonim dari keuangan literasi (Bucher-Koenen, Lusardi, Alessie, \& van Rooij, 2017). Berbagai peneliti telah mengonsepkan makna pengetahuan keuangan melihat area konten berbeda. Huang et al., 
(2013) menganggap pengetahuan keuangan sebagai pemahaman individu tentang konsep keuangan.

Huston, (2010) mengidentifikasi empat komponen utama pengetahuan keuangan setelah meninjau 71 studi: konsep uang dasar, konsep tabungan, pinjaman dan perlindungan. Listiani, (2017) menyatakan beberapa indikator yaitu: menabung teratur dan rutin, menulis target keuangan, melakukan penganggaran, bertanggungjawab, hemat, dan perencanaan keuangan.

Menurut konsep dikemukakan oleh Rotter mengenai locus of control, terdapat dua tipe locus of control, yaitu locus of control internal dan locus of control eksternal. Menurut Crider dalam (Ghufron \& $\mathrm{R}$ Risnawita, 2010) terdapat perbedaan karakteristik dari dua tipe tersebut, yaitu: Locus of Control Internal misal pekerja keras, memiliki inisiatif atau kreatifitas yang tinggi, selalu berusaha untuk dapat memecahkan masalah, berpikir ekfektif, dan punya persepsi usaha harus selalu dilakukan jika ingin sukses. Locus of control eksternal meliputi kurang punya inisiatif atau kreatifitas, mudah menyerah, selalu berpikir jika ada suatu korelasi antara usaha dan kesuksesan dan kurang dalam mencari informasi.

Adapun beberapa hipotesis dalam penelitian ini adalah:

H1:Financial Knowledge berpengaruh terhadap locus of control internal

H2:Financial Knowledge berpengaruh terhadap locus of control eksternal

H3:Financial Attitude berpengaruh terhadap locus of control internal.

H4:Financial Attitude berpengaruh terhadap locus of control eksternal.

H5:Financial Knowledge berpengaruh terhadap perilaku manajemen keuangan.

H6:Financial Attitude berpengaruh terhadap perilaku manajemen keuangan.
H7:Locus of control internal pengaruh terhadap perilaku manajemen keuangan. H8:Locus of control eksternal pengaruh terhadap perilaku manajemen keuangan H9:Financial Knowledge berpengaruh terhadap perilaku manajemen keuangan dimediasi oleh locus of control internal H10:Financial Attitude berpengaruh terhadap perilaku manajemen keuangan dimediasi oleh locus of control internal

\section{METODE}

Penelitian ini mengambil sampel 100 mahasiswa, diambil secara purposive. Variabel yang diajukan adalah PK; Pengetahuan Keuangan, SK: Sikap Keuangan, LCI: Locus of control Internal, LCE: Locus of Control Eksternal, PMK: Perilaku Keuangan. Teknik analisis yang digunakan adalah Structural Equation Modeling (SEM) dengan program software WardPLS. Teknik analisis ini meliputi Pengujian Reliabilitas Skala, validitas skala, nilai estimasi jalur model, model fit indek dari model dan juga untuk pengujian hipotesis. Pengujian hipotesis membandingkan $t$-value dengan nilai kritis sebesar 1.96 dengan probabilitas signifikansi (p) sebesar 0,05.

\section{HASIL DAN PEMBAHASAN}

Hasil validity dan reliability test diketahui bahwa terdapat indikator yang nilainya dibawah 0.5 , sehingga dikeluarkan dari pengukur variabel yaitu indikator pada X1.3, sehingga dilakukan pengukuran ulang dengan validitas dan semua indikator nilainya sudah memenuhi diatas 0.5 . Hasil uji reliabilitas nilai composite reliability coeficient dengan nilai variabel PK sebesar 0.785. untuk variabel SK 0.865, untuk LCI sebesar 0.832 dan nilai untuk LCE sebesar 0.799 serta PMK sebesar 0.817, nilai tersebut sudah diatas nilai 0.7 sebagai syarat diterimanya pengujian reliabilitas. 
Hasil pengujian kelayakan model yang dibangun dalam penelitian ini menghasilkan average path coefficient(APC), average $R$-squared (ARS) dan average varians factor (AVIF) dengan kriteria APC dan ARS diterima dengan syarat $p$-value $<0,05$ dan AVIF lebih kecil dari 5 (Sholihin dan Ratmono, 2013: 61). Pengujian kecocokan model diperoleh hasil Average path coefficient (APC) $=0.217, \mathrm{P}=0.006$, Average $R$-squared $(\mathrm{ARS})=0.138, \quad \mathrm{P}=0.038, \quad$ Average adjusted $R$-squared (AARS) $=0.121$, $\mathrm{P}=0.054, \quad$ Average block VIF $(\mathrm{AVIF})=1.097$, diterima jika $<=5$, idealnya $<=3.3, \quad$ Average full collinearity $\quad$ VIF $\quad(\mathrm{AFVIF})=1.419$, diterima jika $<=5$, idealnya $<=3.3$. berdasar hasil tersebut disimpulkan pengujian model fit banyak memenuhi kriteria, sehingga model penelitian ini dinyatakan sebagai model yang fit.

Estimasi Direct Effect, LCI= 0.211PK+0.0.291SK, Koefisien PK sebesar 0.211 menyatakan bahwa variabel pengetahuan keuangan memiliki arah positif, jika PK berubah satu satuan (naik) dan variabel lain konstan, maka nilai LOI mengalami peningkatan 0.211 satuan. Koefisien SK sebesar 0,291 menyatakan bahwa sikap keuangan memiliki arah positif yang berubah satu satuan (naik) dan variabel lain konstan, maka nilai maka LOI-nya juga kan mengalami peningkatan 0.29 satuan.

Estimasi LCE $=-0.040 \mathrm{PK}-$ 0.0273SK, Koefisien PK sebesar 0.040 menyatakan bahwa variabel pengetahuan keuangan memiliki arah negative. Koefisien SK sebesar 0,0273 menyatakan variable sikap keuangan memiliki arah negative.

Estimasi $\mathrm{MK}=0.154 \mathrm{PK}+$ 0.462SK+0.147LCI-0.126LCE,Koefisien PK sebesar 0.154 menyatakan variabel pengetahuan keuangan memiliki arah positif. Koefisien SK sebesar 0,462 bahwa sikap keuangan memiliki arah positif. Koefisien LCI sebesar 0,147 menyatakan bahwa LOI-nya memiliki arah positif. Koefisien LCE sebesar 0.126 menyatakan bahwa variable LCE memiliki arah negative.

Estimasi indirect effect masingmasing variabel dijelaskan sebagai berikut: $\mathrm{PK} \rightarrow \mathrm{PMK}$ melalui LCI dengan nilai koefisien sebesar 0.036 artinya koefisien estimasi mediasi variabel LCI bernilai positif terhadap pengaruh pengetahuan keuangan dan perilaku manajemen keuangan. $\mathrm{SK} \rightarrow \mathrm{PMK}$ melalui LCE dengan nilai koefisien sebesar 0.077 , artinya bahwa koefisien estimasi mediasi variabel LCE bernilai positif terhadap pengaruh sikap keuangan terhadap perilaku manajemen keuangan.

Hasil uji hipotesis diperoleh hasil berikut: $\mathrm{PK} \rightarrow$ LCI dengan nilai $P$ value sebesar 0.014 mendukung hipotesis, $\mathrm{PK} \rightarrow \mathrm{LCE}$ dengan nilai $P$ value 0.342 tidak mendukung hipotesis, SK $\rightarrow$ LCI dengan nilai $P$ value 0.001 mendukung hipotesis, $\mathrm{SK} \rightarrow$ LCE dengan nilai $P$ value 0.002 mendukung hipotesis, $\mathrm{PK} \rightarrow \mathrm{PMK}$ dengan nilai $P$ value 0.056 tidak mendukung hipotesis, SK $\rightarrow$ PMK dengan 0.001 mendukung hipotesis, $\mathrm{LCI} \rightarrow$ PMK dengan nilai $P$ value 0.065 tidak mendukung hipotesis, LCE $\rightarrow$ PMK dengan nilai $P$ value 0.097 tidak mendukung hipotesis, $\mathrm{SK} \rightarrow \mathrm{LCI} \rightarrow \mathrm{PMK}$ dengan nilai $P$ value 0.358 tidak mendukung hipotesis dan $\mathrm{PK} \rightarrow \mathrm{LCE} \rightarrow \mathrm{PMK}$ dengan $P$ value 0.216 tidak mendukung hipotesis.

\section{Pembahasan}

Pengetahuan keuangan berpengaruh terhadap LOI, Hasil uji menunjukkan bahwa koefisien direct effect pengetahuan keuangan terhadap LOI sebesar 0.211 , variabel pengetahuan 
keuangan memiliki hubungan positif dengan variabel LOI, dapat dimaknai bahwa semakin tinggi pengetahuan keuangan seseoarang maka akan semakin tinggi pula bagaimana seseorang melakukan manajemen keuangan seperti melakukan kontrol, pendanaan dan perilaku penyimpanan.

Estimasi ini didukung dengan nilai signifikansi variabel pengetahuan keuangan sebesar $0,014<0,05$, bahwa ada pengaruh antara pengetahuan keuangan dengan LOI. Hasil ini sesuai penelitian yang dilakukan oleh Perry \& Morris, (2005), kecenderungan konsumen menabung, menganggarkan dan mengendalikan pengeluaran sebagian tergantung tingkat kontrol mereka atas hasil serta pengetahuan dan sumber daya keuangan.

Pengetahuan keuangan tidak berpengaruh terhadap LCE, Hasil pengujian menunjukkan bahwa koefisien direct effect pengetahuan keuangan terhadap LCE sebesar -0.04, yakni variabel pengetahuan keuangan memiliki hubungan negatif dengan variabel LCE, hal ini dimaknai semakin tinggi sikap keuangan seseorang. Hasil ini juga didukung dengan nilai signifikansi untuk variabel pengetahuan keuangan sebesar 0,342>0,05, dapat diartikan bahwa tidak ada pengaruh antara pengetahuan keuangan dengan LCE.

Sikap keuangan berpengaruh terhadap LOI, Hasil analisis menunjukkan bahwa koefisien direct effect sikap keuangan terhadap LOI sebesar 0.291, variabel sikap keuangan memiliki hubungan positif dengan variabel LOI, hal ini dapat dimaknai jika sikap keuangan terkait sisa uang, anggaran dan sikap berhemat seseorang positif maka meningkat juga LOI seseorang.

Sikap keuangan berpengaruh terhadap LCE, koefisien direct effect sikap keuangan terhadap LCE adalah sebesar -0.273 , artinya variabel sikap keuangan memiliki hubungan negatif dengan variabel LCE,hal ini dimaknai semakin tinggi sikap keuangan seseoarang maka LCE akan semakin berkurang tidak percaya diri, tidak inisiatif dan tidak suka bekerja keras.

Pengetahuan keuangan tidak berpengaruh pada perilaku manajemen keuangan, koefisien direct effect pengetahuan keuangan terhadap perilaku manajemen keuangan sebesar 0.154, maka variabel pengetahuan keuangan memiliki hubungan positif dengan variabel perilaku manajemen keuangan, jika pengetahuan seseorang meningkat maka perilaku manajemen akan meningkat. Sikap keuangan berpengaruh pada perilaku manajemen keuangan, bahwa koefisien direct effect sikap keuangan terhadap perilaku manajemen keuangan adalah sebesar 0.462 , artinya variabel sikap keuangan memiliki hubungan positif dengan variabel perilaku manajemen keuangan, ini dapat diartikan bahwa semakin positif sikap keuangan seseorang maka semakin tinggi pula perilaku manajemen keuangannya.

LOI tidak berpengaruh terhadap perilaku manajemen keuangan, bahwa koefisien direct effect variabel LOI akan perilaku manajemen keuangan adalah sebesar 0.147 , artinya variabel LOI berhubungan positif dengan perilaku manajemen keuangan, dapat maknai bahwa semakin positif LOI maka semakin positif juga perilaku manajemen keuangannya.

LCE tidak berpengaruh terhadap perilaku manajemen keuangan, bahwa koefisien direct effect variabel LCE terhadap perilaku manajemen keuangan adalah sebesar -0.126, artinya variabel LCE memiliki hubungan negatif dengan variabel perilaku manajemen keuangan, hal ini 
menunjukkan bahwa semakin rendah LCE maka akan semakin tinggi perilaku manajemen keuangannya.

Pengetahuan keuangan tidak berpengaruh terhadap perilaku manajemen keuangan melalui LOI, koefisien inderect effect variabel pengetahuan keuangan terhadap perilaku manajemen keuangan melalui LOI sebesar 0.036, artinya variabel pengetahuan keuangan berhubungan positif dengan variabel perilaku manajemen keuangan melalui LOI, jadi jika ada mediasi variabel LOI maka akan positif juga perilaku manajemen keuangan. Tapi variabel LOI bukan variabel tepat memediasi hubungan antara sikap keuangan dengan perilaku manajemen keuangan

Sikap keuangan tidak pengaruh terhadap perilaku manajemen keuangan melalui LOE, bahwa koefisien indirect effect variabel sikap keuangan terhadap prilaku manajemen keuangan melalui LOE adalah sebesar 0.077, artinya variabel sikap keuangan memiliki hubungan positif dengan varibel perilaku manajemen keuangan melalui LOE, variabel mediasi ini memiliki arah positif dalam hubungan tersebut. Namun demikian LOE bukan variabel mediasi hubungan perilaku manajemen keuangan.

\section{SIMPULAN}

Berdasarkan hasil analisa dan pembahasan diatas dapat disimpulkan Pengetahuan keuangan berpengaruh terhadap LOI, pengetahuan keuangan tidak berpengaruh terhadap LOE, sikap keuangan berpengaruh terhadap LOI, sikap keuangan berpengaruh terhadap LOE, pengetahuan keuangan tidak berpengaruh terhadap perilaku manajemen keuangan, sikap keuangan berpengaruh terhadap perilaku manajemen keuangan, LOI tidak berpengaruh terhadap perilaku manajemen keuangan, LOE tidak berpengaruh terhadap perilaku manajemen keuangan, dan locus of control baik internal dan eksternal belum mampu menjadi pemediasi antara pengetahuan keuangan, sikap keuangan terhadap perilaku manajemen keuangan

\section{DAFTAR PUSTAKA}

Al Kholilah Rr Iramani, N. (2013). Studi Financial Management Behavior Pada Masyarakat Surabaya. Journal of Business and Banking, 3(1), 69-80.

Annamaria Lusardi, O. S. M. A. V. C. (2010). Financial Literacy among the Young. The Journal of Consumer Affairs,44(2), 358-380

Berry, J., Karlan, D., \& Pradhan, M. (2018). The Impact of Financial Education for Youth in Ghana. World Development, 102, 71-89. https://doi.org/10.1016/j.worldde v.2017.09.011

Bucher-Koenen, T., Lusardi, A., Alessie, R., \& van Rooij, M. (2017). How Financially Literate Are Women? An Overview and New Insights. Journal of Consumer Affairs, 51(2),255-283. Fernandes, D., Jr, J. G. L., Netemeyer, R. G., \& Fernandes, D. (2014). Financial Literacy , Financial Education , and Downstream Financial Behaviors Financial Literacy , Financial Education , and Downstream Financial Behaviors, (October).

Garg, N., \& Singh, S. (2018). Financial literacy among youth. International Journal of Social Economics, 45(1), 173186.https://doi.org/10.1108/IJSE11-2016-0303

Ghufron, M., \& R Risnawita. (2010). Teori psikologi. Jogjakarta: ArRuzz Media Group. 
Herdjiono, I., \& Damanik, L. A. (2016). Pengaruh Financial AttiTude, Financial Knowledge, Parental Income Terhadap FinancialManagement Behavior. Jurnal Manajemen Teori Dan Terapan, 9(3), 226-241.

Huang, J., Nam, Y., \& Sherraden, M. S. (2013). Financial Knowledge and Child Development Account Policy: A Test of Financial Capability. Journal of Consumer Affairs,47(1),1-26.

https://doi.org/10.1111/joca.1200

Huston,S.J.(2010).Measuring

Financial Literacy. The Journal of Consumer Affairs, 44(2),296-316

Ida, \& Dwinta, C. Y. (2010). Pengaruh Locus o Control, Financial Knowledge, Income Terhadap Financial Management Behavior. Jurnal Bisnis Dan Akuntansi, 12(3), 131-144.

Listiani, K. (2017). Pengaruh Financial Knowledge, Locus of Control Dan Financial Attitude TerhadapFinancial Management. Prints.Perbanas.Ac.Id.

Lusardi, A., \& Olivia S. Mitchell. (2007). Baby Boomer retirement security: The roles of planning, financial literacy, and housing wealth. Journal of Monetary Economics, 54(1), 205-224. https://doi.org/10.1016/j.jmoneco. 2006.12.001

Mandell, L., \& Klein, L. S. (2009). The Impact of Financial Literacy Education on Subsequent Financial Behavior. Journal of Financial Counseling and Planning, 20(1), 15-24.

Nababan, D., \& Sadalia, I. (2012). Analisis Personal Financial Literacy dan Financial Behavior Mahasiswa Strata I Fakultas Ekonomi Universitas Sumatera Utara. Retrieved from http://www.wordreference.com/si nonimos/exhaustivo

Pankow, D. (2010). Financial Values, Attitudes and Goals. Financial Planning, 591(September).

Perry, V. G., \& Morris, M. D. (2005). Who Is in Control? The Role of Self-Perception , Knowledge , and Income in Explaining Consumer Financial Behavior. The Journal of Consumer Affairs, 39(2), 299-313.

Ricciardi, V., \& Simon, H. K. (2000). What is Behavioral Finance? Business, Education and Technology, 1-9.

Rotter, J. B. (1966). Generalized Expectancies For Internal Versus External Control Of Reinforcement. Psychological Monographs: General and Applied,80(1).https://doi.org/10.1 037/h0092976

Scafidi, B., \& Skimmy-, B. (2016). The Effects of Perceived and Actual Financial Literacy on Financial Behaviors. Economic Inquiry, 54(1), 675-697. https://doi.org/10.1111/ecin.12255

Sohn, S., Joo, S., Grable, J. E., Lee, S., \& Kim, M. (2012). Adolescents fi nancial literacy: The role of fi nancial socialization agents, fi nancial experiences, and money attitudes in shaping fi nancial literacy among South Korean youth. Journal of Adolescence, $35(4)$, 969-980. https://doi.org/10.1016/j.adolesce nce.2012.02.002

Supanantaroek, S., Lensink, R., \& Hansen, N. (2017). The Impact of Social and Financial Education on Savings Attitudes and Behavior Among Primary School Children in Uganda. Evaluation Review, 41(6),511-541.https://doi.org/ $10.1177 / 0193841 X 166657199$. 